\title{
Culturological Analysis of Filmic Border Crossings: Popular Geopolitics of Accessing the Soviet Union from Finland
}

\author{
Juha Ridanpää (Geography Research Unit, University of Oulu)
}

\begin{abstract}
Recent studies in popular geopolitics have emphasized how films and the film industry play a significant role in the process of constructing politically charged worldviews, stereotypes of the 'other', as well as in the cultural reproduction of world politics. The production and screening of films takes place within certain social and geopolitical circumstances, which set the limits and the scope of perspective as far as what is a permissible, advisable or correct manner for film makers to approach certain politically charged topics. This paper discusses the geopolitical circumstances through which the national border of Finland and the Soviet Union has become an elementary part of the content of films, and how films focusing on the problematics of border crossing have a certain operational function within the context of their own creating. The specific focus is on how world geopolitics, in this case the Second World War, sets the limits for a film industry concerning what topics are suitable for audiences, how the act of crossing a border becomes a filmic event through which national identity is constructed and maintained, and how films play an operative role in the game in which foreign relations are performed, in this case in the politics of Finlandization. The material discussed consists of three films: Yli Rajan [Over the Border] (Ilmari 1942), Tuntematon Sotilas [The Unknown Soldier] (Laine 1955) and Born American (Harlin 1986).
\end{abstract}

Keywords: border crossing, border film, popular geopolitics, Finnish-Russian border

Ridanpää, J. (2017). Culturological analysis of filmic border crossings: Popular geopolitics of accessing the Soviet Union from Finland. Journal of Borderlands Studies, 32(2), 193-209.

\section{Introduction}

In the geopolitical analysis of films it has been emphasized how the film industry plays a significant role in the process of constructing politically charged worldviews as well as in the cultural reproduction of world politics (Dodds 2003). Films matter to people and form "an important part of their popular geopolitical repertoire" (Dodds 2008a, 476). The notable sociopolitical aspects of border crossing in films have often been pointed out, but it is equally important to understand how the films themselves, as well as the entire industry developed around them, operate as political agents (Carter and McCormack 2006; Ridanpää 2014). Films are not simple reflections or representations of past and current geopolitical climates, but also function as active instruments in the process of forming and re-forming international relations. The production and screening of films takes place within certain social and geopolitical circumstances, which set the limits and the scope of perspective as far as what is a permissible, advisable or correct manner for film makers to approach certain politically charged topics. 
The international relations between Finland and the Soviet Union, especially during the World War II and Cold War periods, have worked as a unique framework for the Finnish film industry, one which from the viewpoint of popular geopolitics is highly interesting. In Finnish films the topic of crossing the border, from Finland to the Soviet Union, has always been a politically loaded theme, and the recently resuscitated debate about the politics of Finlandization puts these old films in a new light. This paper discusses the geopolitical circumstances through which the national border between Finland and the Soviet Union become an elementary part of the content of films, and how film that focus on the problematics of border crossing have a certain operational function within the context of their own makings. The methodology applied here relies on Fairclough's (1992a; 1992b) manner of understanding social and cultural change as a linguistically based process in which intertextual meanings of social identities and relationships are constructed and negotiated through the discursive practices of producing, distributing and consuming. Films are approached here as 'discursive events' which are discussed and analyzed by counter-reading their intertextual nature against the geopolitical history of Finland and its relationship with the Soviet Union/Russia. The study of discursive events refers here to the examination of what is happening at a certain time within a certain social, cultural and political context (Fairclough 1993).

The focus of this paper is on three films which have had specific roles of geopolitical agency in the context of Finnish foreign relations with the Soviet Union/Russia. The material discussed consists of Yli Rajan [Over the Border] (directed by Väinö Ilmari 1942), Tuntematon Sotilas [The Unknown Soldier] (directed by Edvin Laine 1955) and Born American (directed by Renny Harlin 1986). These films are discussed in chronological order: Through a brief analysis of Over the Border, it is discussed how particular geopolitical circumstances, in this case World War II, set the limits for the film industry concerning what topics are suitable for audiences. Through discussing The Unknown Soldier, it is scrutinized how the act of crossing a border becomes a filmic event through which national identity is constructed and maintained. Through dissecting Born American, it is discussed how films have an operative role in the game in which foreign relations are played, in this case the politics of Finlandization.

Introducing this, the paper discusses how films have been approached in the studies of popular geopolitics and how the theme of border crossing has become a unique topic and perspective in films, 'border films'.

\section{Popular geopolitics and geopolitical agency of films}

The realm of politics has been approached in the film industry in many ways. Global geopolitics is a constantly present theme and is not bound to any specific film genre. Films very often involve political image making in which the ways to comprehend complicated political processes, the structuring of national identities and so on, are created, shaped and molded for 'common people', that is, for audiences (cf. Dodds $2008 \mathrm{~b}$ ). The rise in the success (and number) of disaster movies, for example, has been 
interpreted in popular geopolitics as being in direct connection to a specific geopolitical event: 9/11 has inspired the popularity of disaster movies in remarkable fashion (Power and Crampton 2005, 193). Similarly, Dittmer (2011) has pointed how the cinematic 'superhero boom', the explosion in filmic representations of superheroes, has resonated with post-9/11 US foreign policies in several ways, underlining especially how superheroes articulate American exceptionalism - a particularly American geopolitical vision and sense of self (Dittmer 2011, 114). In that sense Hollywood comes on the footsteps of world geopolitics. As the Cold War has turned into the global war on terror, the locations where James Bond combats global crime have moved, at the same time altering representations of Russia, the Middle East and 'the Orient' in general (see Dodds 2003, 2005).

The connection between geopolitically charged films and the geopolitical circumstances within which they are made and consumed is a complicated and much studied topic in the field of popular geopolitics. In these studies it has been emphasized how the film industry plays a major role in the process of constructing geopolitically charged stereotypes as well as in the cultural reproduction of world politics (Dodds 2003). Popular geopolitics, as one of four directions in critical geopolitics (see Ó Tuathail 1996), has underscored a specific "recognition of geopolitics as something everyday that occurs outside of academic and policymaking discourse" (Dittmer and Gray 2010, 1664). Especially political ideologies are something that is not learnt through academic or policymaking discourses but rather through more or less banal everyday practices such as films. According to Dalby (2008), a good example of how political ideologies and their implementation through foreign policies are connected to film making is evident in Ridley Scott's three movies Gladiator (2000), Black Hawk Down (2001) and The Kingdom of Heaven (2005) where a current general tendency of the 'war on terror', the necessity for warriors to fight wars in distant lands, is taken allegorically into other similar contexts. Respectively, 'non-Western' films that discuss the 'war on terror' can be understood as 'a cinematic challenge', the vantage point of the 'other' in which so-called unstable regions attain their own geopolitical, or rather 'anti-geopolitical' agency through filmic counter-arguments (Anaz and Purcell 2010).

In films places are not simply passive backdrops but rather help to shape storylines and draw attention to the prevailing geopolitical climate (Dodds 2005, 285). Movies construct and shape the background against which people approach geopolitical crises, for instance (see Power and Crampton 2005). In addition, as Dodds (2003, 126-127) argues, contemporary geopolitical anxiety is often beneficial to the commercial success and worldwide popularity of films. In similar vein, film reviews continuously establish interpretative patterns through which viewers can comprehend the geopolitical world. Films are not received and evaluated 'as they are', but within and against wider contextual frameworks in which film reviews play their own part. Film reviews function as 'guide books' for the audience, offering multiple 'instructions' on how to understand not only the content of the film itself, but also world politics and their spatial dimensions in general (Ridanpää 2014). The educational potential of films has also been acknowledged; it has been argued, for instance, that Avatar (2009) "has the potential to help students grasp the dynamics of imperial/indigenous relationships in 
part because it removes the discussion from the level of historical and personal blame and into the realm of a science fiction adventure" (Madsen 2014, 47).

It has long been common for the film industry to use geopolitical crises for financial gain. Film production entails specific territorial strategies and limitations, as well as 'territorial appeals' such as to regional and national identities (Coulter 2011), which for example in the case of Post-Wall German filmmaking has involved acknowledging numerous issues concerning timing and taboos (Coulter 2013). In similar fashion to many other popular representations, films have a major influence over how people perceive national images and identities, both their own as well as those of other nations. James Bond is a classic example of a series of films that have molded the manners of perceiving a specific nation, essentially recasting the national image of Britain (Black 2004; Dodds 2003). Consequently, films exert influence over political decision making, and contrarily, politicians have long used films to legitimate their political decisions (Dodds 2008b, 1626). Wartime propaganda films are probably the most flagrant examples of this.

Geopolitical themes have been strongly present in films, but it is also (and probably more so) important to figure out how films operate as political agents. A film is not just a reflection or representation of past and current geopolitical climates, but also an active agent in the process of how international relations are formed (Ridanpää 2014). This comes close to what Carter and McCormack (2006) call 'cinematic interventions'. According to Carter and McCormack (2006, 232-233), there are three different ways or logics as to how cinematic intervention can simultaneously be geopolitical

intervention: Firstly, in cinematic scripting, through the representational logics of film; secondly, as a matter of production and reproduction of particular geopolitical logics and 'ways of seeing'; and thirdly, through performative logics, as particular modes and styles of acting. What could be added to Carter and McCormack's grouping is how films also, in a practical manner, influence and operate on the level of 'practical geopolitics', that is, on the level of foreign affairs, bureaucracy and political

institutions (see Ó Tuathail and Dalby 1998, 4-5). This is a reciprocal process in which the geopolitical world, with all its 'seriousness' and rigidity, is consumed on the level of everyday, and vice versa; films that are usually considered popular entertainment may attain 'official' political agency from outside their everyday banality.

\section{Politics of border films}

One form of the geopolitically charged film type are the so-called 'border films' which have recently been considered to form a unique sub-genre of their own: "The "border film' (in all is generic and geographical diversity) does bring to the fore the manner in which discourses, practices, sites, objects, and bodies implicated in borders, sovereignty and territory are dramatised by Hollywood and beyond" (Dodds 2013, 568). In the context of films, borders should not be conceived of as simple lines on state maps, but rather as unique sites of action and mobility where the order of world politics, with all its complexity, becomes materialized. In contemporary Hollywood films the theme of border crossing has conventionally been approached mainly within 
the context of modern societal problems. Films are typically set on the US-Mexico border, a stage, on which the social problems and consequences of criminal activities, mainly drug trafficking and illegal immigration, are performed (Mains 2004; Beckham 2005; Dell'agnese 2005; Dodds 2013).

In the case of the US-Mexico border, the films provide a context for producing and interrogating discourses of nationalism, nativism, and fear about borders and various forms of border crossing (Mains 2004). With the recent development of refugee policies, the border has turned into a site of danger where the clean internal community and national identity are protected from outside pollution (Haddad 2010). According to Fojas (2007), in a similar manner the Hollywood border films of 1980s' represented the symptoms of cultural unrest and political uncertainty with clear moral lessons. Fojas $(2007,98)$ describes this b-grade film genre as 'boorishly nationalistic' 'bordersploitation':

Each film plays out the same drama and the same topoi again and again, as if the work of the first incarnation was left unfinished and the borders were a national wound that refused to heal. The borderlands are containers of traumatic material and unassimilated histories repeated endlessly in the dream work of Hollywood cinema. The current slate of border films and television dramas - Extreme Prejudice (1987), Deep Cover (1992), Traffic (2000), Blow (2001), Kingpin (NBC 2003), and A Man Apart (2003) - reopen the trauma of Hollywood film and television border images. The US is again heroic, and though Latinos are represented with greater nuance, this is not achieved without sacrifices, without reactivating a Hollywood history of the dark mythology of the borderlands that intensify phobias about external threats to national health and "homeland security."

As Maciel (1990, 2) pointedly notes: "there is no greater cultural manifestation of the general image and widely held perceptions of the U.S.-Mexican border than the cinema". In Hollywood films the US-Mexico borderland has long been mythologized, which, from the viewpoint of local Mexican people, has basically meant the construction of stereotyped, pejorative image of their everyday life. On the other hand, it has been argued that when the focus in films is on local people and their everyday experiences, especially those living on the Mexican side of the border as in Lone Star (1996), border film can attain certain informative value. At the same time the depiction of locality turns from the stereotyped view into an authentic view (Arreola 2005). However, from the viewpoint of establishing and maintaining patriotic ideologies, the instrumental value of border films is obvious. Phobias about external threats to national health compose a scheme through which intriguing dramas can easily be narrated and wide audiences appealed to.

As in globally distributed, successful Hollywood films criminal activity is the most common theme and context of filmic border crossing, in the films from 'beyond Hollywood' there can be found other geopolitically charged themes as well. Diasporic identity as a human condition is currently an extremely topical and also highly problematic process of sociopolitical and geopolitical development, which as a filmic 
theme has been increasingly present, especially in European films (see Ahonen et. al. 2013). However, it is important to emphasize that although for example the sociocultural impacts of the Turkish diaspora in Germany is a common filmic theme, the act of border crossing per se, mobility, is relatively rarely presented (Gallagher, 2013). Another theme of specific interest in German cinema has been the geopolitics of the Iron Curtain (Miller, 2013), also present in Born American, the film discussed in this paper.

In similar fashion to how images help to redefine a border, films emphasize the diversity and complexity of borders (Ball 2014). The relationship between a border and a border film can be understood in two ways. Firstly, border films can be seen as representations of cultural meanings connected to borders, which for their part can construct new conceptions, or strengthen and legitimize or contest old ones. The various manners of constructing, confirming and deconstructing meanings related to borders are creative and also imaginative in many ways, but in the filmic approach borders themselves are often treated as natural. Films and the film industry are institutions in which borders, in a relational manner, express their place, while border films work accordingly as routes to re-narrate the contents and meanings of changing national identities, of which the filmic representations of the West German national identity is an enlightening example (see Scharf 2005). In the continuous process of crossing borders, filmic spaces or cinematic 'realities' are produced, which Escher $(2006,308)$ uses to refer to mainly culturally defined barriers, such as religious taboos. Filmic border crossing is thus seen here as a method for broadening world conceptions, opening new manners (for the audience) to perceive the world (see Escher 2006, 309).

\section{Over the Border: War, love and the politics of film making}

As mentioned, within the genre of border films, it is usual that the focus is on criminal activities that take place at the border; in Finnish border films it is often emphasized how crossing the border, from Finland to Russia, is a criminal activity in itself. The context for these films is usually Finland's geopolitical relationship with its neighboring superpower Russia/the Soviet Union, particularly times when the disagreement over the location of the border has been topical, that is, wartime generally but World War II especially. Currently, Finland has a 1313-km-long border with Russia, the location of which has been a subject of negotiation several times. Finland was an autonomous Grand Duchy of Russia from 1809 to 1917, when independence was gained. Before 1809 Finland had been an administrative part of Sweden from the $12^{\text {th }}$ century onwards. The history of the Finnish eastern border originated in the Treaty of Nöteborg (in Finnish: Pähkinäsaaren rauha) on 12 August 1323, when the first settlement between Sweden and the Novgorod Republic was established. During the period around World War II, the border between Finland and Russia changed twice. The regions of Karelia, Petsamo and Salla were ceded to the Soviet Union, an area that amounted to $12.5 \%$ of Finland's territory, ending in resettlements of 420,000 citizens. It is argued that the consequences of these border 'negotiations' have created a national trauma which was under a certain level of taboo until the collapse of the Soviet Union (Paasi 1999, 672). 
During World War II, Finland was at war against the Soviet Union from 30 November 1939 to 13 March 1940 (The Winter War), and from 25 June 1941 to 19 September 1944 (The Continuation War). The activities of the film industry were firmly controlled by the state during wartime (Sedergren 1999). During 1940-44 approximately 92 films a year were published while the corresponding number before the war was approximately 140 (Sedergren 1999, 165). Yli Rajan [Over the Border], directed by Väinö Ilmari during the war in 1942 and based on a book of similar name by Urho Karhumäki published before the war in 1938, is a good example of a border film in which geopolitical circumstances play a major role in the story as well as a thematic factor in the process of how the film was distributed and consumed. The events in the film happen in the south-eastern Karelia region in the 1930s. The film tells a melodramatic love story of a Finnish man and a Russian (Ingrian) girl, who, in order to meet each other, have to disobey the law, crossing the border secretly by night. At the same time the film is a story about a border between two nations which in an almost active manner influences the daily activities of the protagonists by preventing a loving couple from meeting each other and getting married. Over the Border is a love story where the border has several roles and functions simultaneously and on different levels. The film begins with a strong territorial image showing the map of Karelia, the border between two countries in the middle; and the title of the film and opening credits appear as the map becomes - in symbolic manner - 'split in half', along the borderline (Figure 1). After the opening credits, the torn borderline closes again and the story about restricted love begins, with a view of a cold forest with a fence made of barbed wire demarcating the border between two nations and a loving couple.

Specific scenes, those where the act of crossing the border is a climax in the storyline, turn into cinematic allegories for wider geopolitical relations between Finland and the Soviet Union. Although Over the Border is based on a novel written before the war, it is easy to interpret the plot turns in this love story as politically loaded messages. What makes these sorts of interpretations even more plausible was that during wartime almost all popular entertainment was controlled and censored by the state, as the possibility that films might be used as weapons, in the manner of covert propaganda, was always suspected (see Koppes and Black 1987). Interestingly, Over the Border was the first internationally awarded Finnish film, at the Venice Film Festival in 1942, and it has been argued that the Medaglia della Biennale award was given mostly due to film's anticommunist tendency (Uusitalo 1977, 113). Compared for example to German propaganda films, Over the Border was not actually a war propaganda film, but a propagandistic message is nevertheless clearly evident and was doubtlessly foisted purposely. Thus, the film both represents the geopolitical climate and also attains certain geopolitical agency by playing a notable practical role in the process of how the political content of films becomes sustained and reformed. 

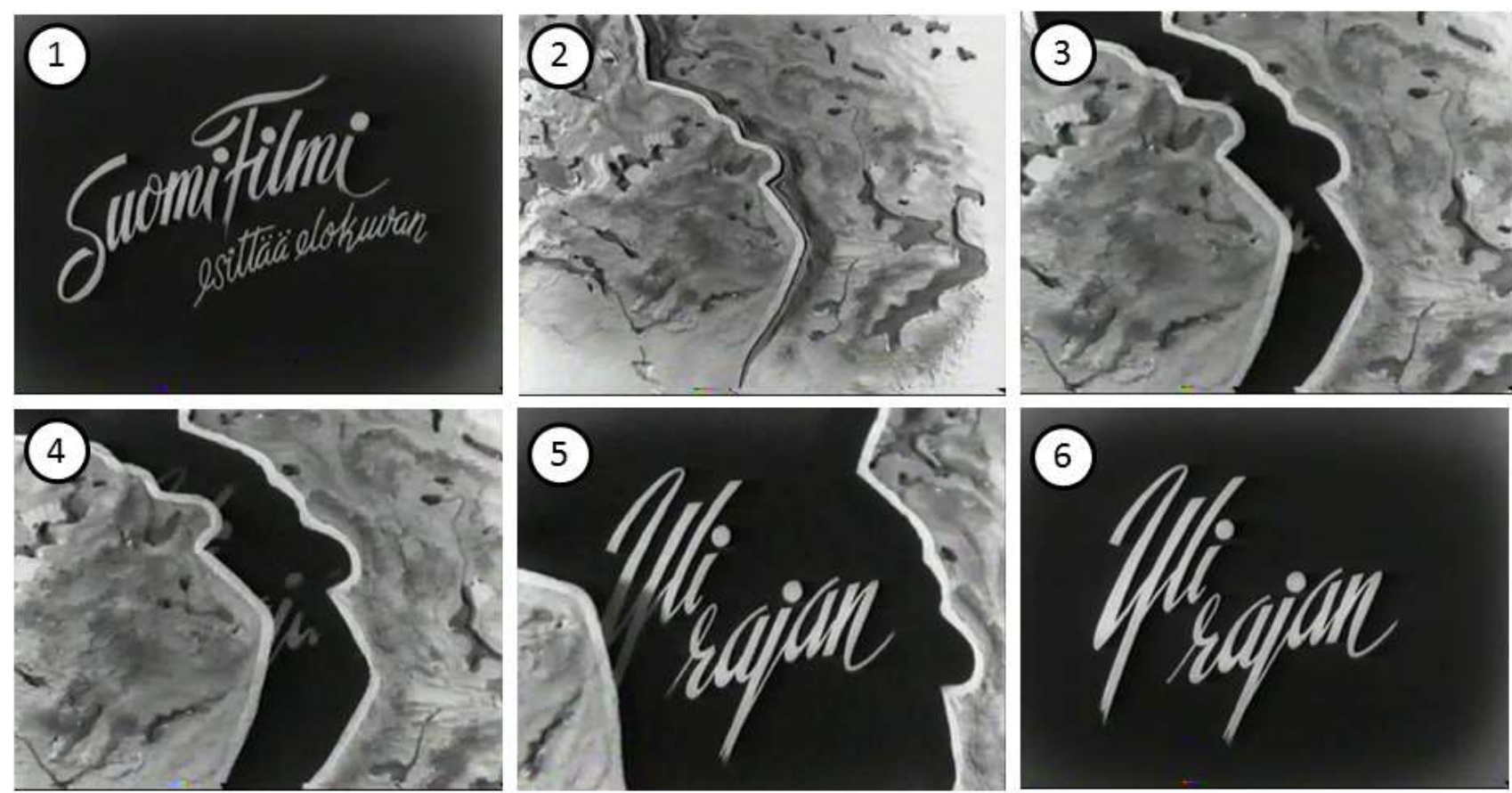

Figure 1. The opening from Over the Border (1942): (1.) First comes an introductive text "a Film presented by Suomi Filmi", after which (2.) a painted map of Karelia appears with a crack in the middle, the border between Finland and the Soviet Union, (3.-4.) which broadens, (5.-6.) uncovering the title of the film, "Over the Border".

During the war, the Finnish film industry was systematically controlled by the state on the grounds of geopolitical and military imperative. The rules about distributing film materials - mainly news reports, documentaries, propaganda and especially raw film material from the battlefield - was a topic negotiated with wartime ally Germany, and was an important issue in terms of how comradeship-in-arms between Finland and Germany was forged (Sedergren 1999, 171-176). Regulations over how the representations of Eastern Finland should be restricted came in July 1942. The office of chief commander gave regulations according to which the topics of religions and their arrangements, school and education under the Soviet Government, economic wealth and landowning, the development of transport, incorporation of regions into Finland and the prospective demarcation of borders, were forbidden topics. In addition specific restrictions were given as regards describing the Soviet people and culture (Sedergren 1999, 174-175). As a result, the melancholic story about love across the border was censored. After the war Over the Border was not categorized as an officially censored film, but rather it was put on an unofficial list of those films which were "not desired to be distributed", and thus later was considered, by the film producers themselves, one of the many anti-Soviet films that had to be banned after World War II (Sedergren 2006, 59-61; see also Uusitalo 1977). The last screening of Over the Border was in July 1944, after which 50 years elapsed before the film was screened again, on a national TV broadcast. 


\section{The Unknown Soldier: Borders and national identity}

Before World War II, in Finnish education and popular discourses the Soviet Union was represented through a specific dark view of the 'other' in which the eastern border "became a mythical manifestation of the eternal opposition between two states and a crucial constituent of Finnish national identity" (Paasi 1999, 671). Earlier, at the turn of the $20^{\text {th }}$ century, educating and enlightening the populace through the school system and institutional organs had a considerable role in the process of nationbuilding by reasserting nationalist ideologies. Nation-building was established through popular movements and new organizations, which at the same time diverted people's interests on a new, governmental level (Heinonen 1998; Suodenjoki 2012; Häkli 1999, 137). After independence, the newly established border started rapidly distinguishing people as 'insiders' and 'outsiders', for example through the estate ownership legislature developed by the Finnish government (Lam 2012), while the antipathy among Finnish people towards the Russian people became stronger in popular media and rapidly morphed into strong racist hatred (Karemaa 2004). In similar fashion, after World War II the general attitude towards the Soviet Union remained hostile (Vihavainen 2004).

Due to the geopolitical history of Finland, compared to the borders between Finland and Sweden and Norway, which have been seen more as open borders, the border with Russia has been conceived of as a border that divides (Paasi and Prokkola 2008). In this sense, the border between Russia/the Soviet Union has held unique, deep symbolic meaning for national identity narratives as a barrier that separates Finland from the threatening 'other' (Paasi 2011, 23). Tuntematon Sotilas [The Unknown Soldier], directed by Edvin Laine in 1955, is an example of those films in which national identity becomes constructed through antipathy towards a neighboring country. The story of The Unknown Soldier takes place in 1941, when Finland attacks the Soviet Union to regain the territory the Soviet Union occupied after the Winter War of 1939-1940. The Unknown Soldier is a realistic story where the myth of the noble, obedient Finnish soldier becomes contested, told from human perspective, from the viewpoint of ordinary Finnish soldiers and their human relationships reminiscent of All Quiet on the Western Front (1930), as often mentioned by film critics (Jokinen and Linko 1987, 12). This nonetheless has not prevented the story from becoming a sort of 'bible' of Finnish national identity - in fact Väinö Linna's original novel has become the most-read book in Finland (after the Bible). Although the original novel has been adapted in several filmic and theatre versions, Laine's adaption has generally been considered the most canonical (Jokinen and Linko 1987, 92-93). According to Celli (2011), a key characteristic of the Finnish cinema is a ruralurban split and Celli considers The Unknown Soldier one of the best examples of the rural essence of Finnish national identity (Celli 2011, 35-37). In the Finnish national narrative, border guarding is imagined as masculine assignment in which the capacity to control the border and protect the homeland is ultimately a matter of being capable to act and survive in the arctic environment (Prokkola and Ridanpää 2014).

Although not actually a border film as such, compared to Ilmari's Over the Border for instance, the film includes several scenes in which the topic of national identity 
becomes discussed through the theme of border crossing, or border violation. If in Over the Border the border between Finland and the Soviet Union was the main topic of discussion, in The Unknown Soldier the border represents, as in innumerable other war films, a national treasure which needs to be protected. The border is 'a marker of sovereignty' (Dell'agnese 2005, 212), which is continuously challenged during wartime. In the middle of the film there is one epic scene concerning border crossing where a group of Finnish soldiers arrive from the forest to a clear-cutting of trees and start chatting sarcastically about the significance of the moment:

Koskela: Boys, it's the old border.

Hietanen: Right, this boy's going abroad right now.

Salo: We're in Russia, boys.

Lahtinen: That we are. And this is where our rights end. From now on, we're plundering.

Sihvonen: Oh, so we're crooks when we cross borders? The others are protecting national security when shifting borders.

Salo: Who knows, maybe we'll stop here. They say it'll be over in three weeks. Then we can go haymaking.

Lahtinen: Brought to you by The Horsemen's News Agency.

After this the camera pivots right to show an image of soldiers crossing the border, the old border between Finland and the Soviet Union from before the Winter War, which is represented as a strict line leading into a vanishing point on the horizon in onepoint perspective (Figure 2). This image of Finnish soldiers marching from Finland to Russia during the Continuation War, crossing "the Old Border", is familiar to many Finnish people, not only from The Unknown Soldier, but also from several famous war photographs as well. In recent border studies the concept 'borderscape' has been approached from various viewpoints (Rajaram and Grundy-Warr 2007), and although this image from The Unknown Soldier does not precisely signify the 'borderscape' of border scholars, this image cannot be considered a single, insignificant landscape scene from the film. This image signifies much more. It is a 'cinematic landscape' (see Lukinbeal 2005) in which the scene is transformed, through 'border art', into a political artscape (see Szary 2012). It is a 'filmic borderscape' in which Finland's long geopolitical history and one of its most important turning points are captured in a single scene; it signifies and evokes the Finnish government's historic goal of establishing 'Greater Finland', a nation that would extend further east to its 'natural' borders - borders which, based on 'scientific evidence', were featured in several propaganda maps as being the true outline of what Finland should be (Paasi 1996; Kosonen 2008). "Borderscape is the border", as Schimanski (2015, 36) formulates it. The image of soldiers crossing the border represents an act of taking the imaginary homeland' back. It is a view in which border crossing is used in symbolic manner as an allegory for what national pride and defending independence, in the case of Finland, is all about. Soldiers stepping across the old border is a symbolic maneuver in which protecting the nation, the collective 'us', is represented as a masculinist endeavor to protect the body of the Finnish Maiden (Suomi-neito), 'our' Finland, from outside threat (see Prokkola and Ridanpää 2014). 


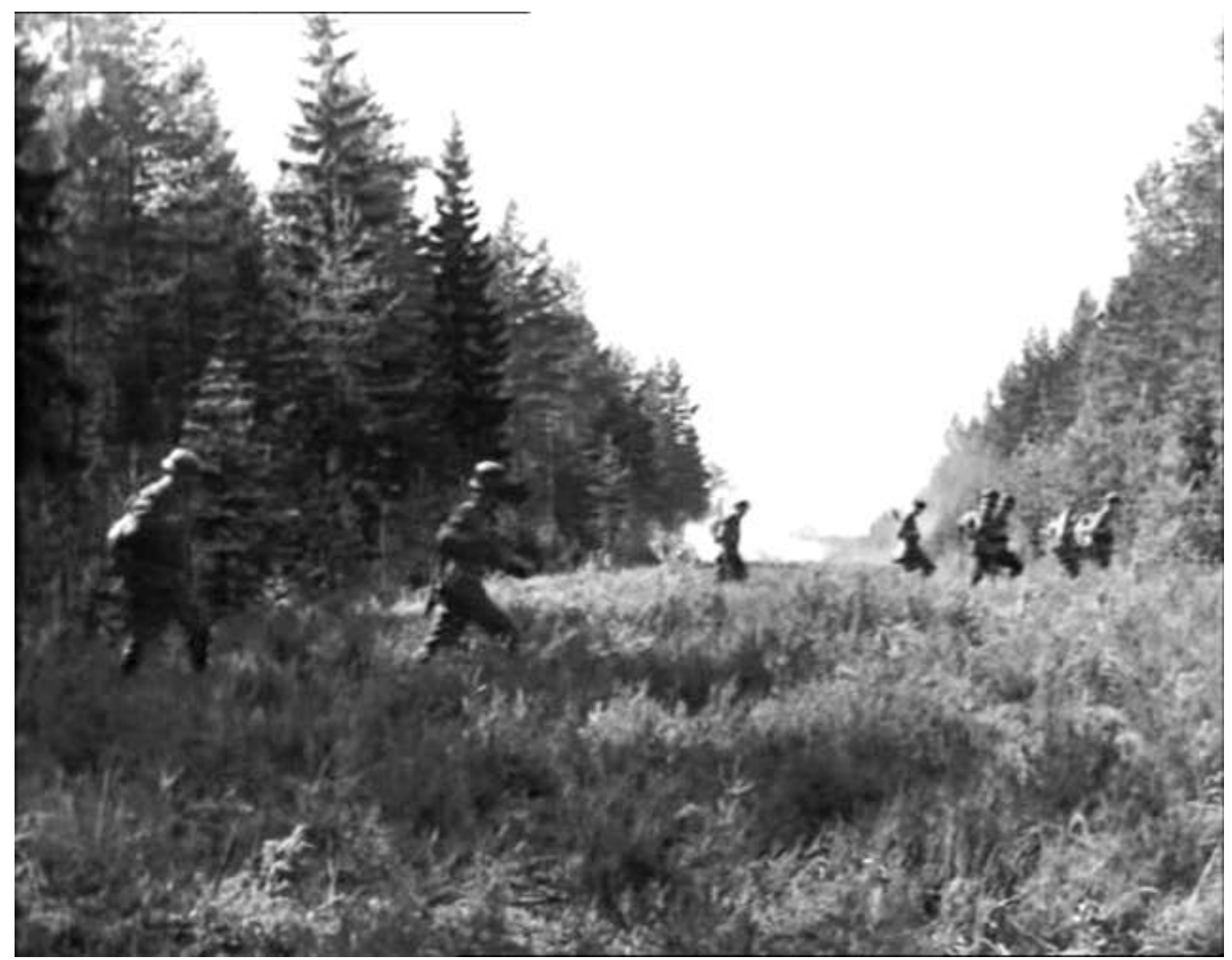

Figure 2. Finnish soldiers crossing the 'old border' from Finland to the Soviet Union in The Unknown Soldier.

In many cases, films can be interpreted as banal reproductions of nation and nationalism (cf. Billig 2005), but The Unknown Soldier in some ways exceeds the level of banality. Although the original book as well as the film in part contest nationalistic values (see Varpio 2006, 320-342), the story has become an icon of Finnish national identity, an icon of national pride which - importantly - has also been actively sustained by the Finnish state: since 1999 Finnish public national broadcaster YLE has shown the film every year on Independence Day. For many people/families watching The Unknown Soldier is an annual ritual, a nationalistically charged banal practice that has been actively supported by the state. The only problematic issue that has ever been raised concerns whether the afternoon is actually a proper time to show a film containing realistically graphic sequences of war violence. This became topical in 2012 when the Centre for Media Education and Audiovisual Media demanded the film be shown after 5 p.m. The justification for the early broadcast time was given by YLE Management: that watching The Unknown Soldier is a "Finnish tradition" and "very important for adult audiences" (Mällinen 2012). Showing the film every year on Independence Day, in the afternoon, has strengthened its position as an official and true national narrative of Finnish identity, at the same legitimizing the high esteem of the film itself (Varpio 2006, 642). 


\title{
Born American: Popular Geopolitics of Finlandization
}

Born American, the debut film of Finnish director Renny Harlin and released in 1986, is an interesting example of a film where geopolitical climate, international relations and the interests of film makers collide - in the context of border crossing and the Cold War. At the time, Born American was the most expensive film ever made in Finland. Harlin, who has since directed 19 films, mostly Hollywood action films, has become known for his controversial manner of approaching Russian society, politics and policies (see Kirchick 2011). For example, one of his latest films, 5 Days of War (2011), a film focusing on the war between Russia and Georgia, has been criticized for containing exceptionally harsh anti-Russia propaganda. Born American tells the story of three American students spending a vacation in Finland who decide to cross the border into the Soviet Union - just for fun - well aware that if they get caught, the consequences may be serious. The film begins with an opening text:

\author{
Russia's Iron Curtain stretches thousands \\ of miles across Europe. \\ In some places it is heavily fortified. \\ In some places it consists of nothing \\ more than a barbed wire fence. \\ Accidental border crossings are \\ not uncommon....
}

The opening text works to foreshadow forthcoming events, at the same time opening the wider geopolitical context (the border context) within which the story will unfold. From the very beginning it is made clear to the audience that the film is ultimately about geopolitics and not just three American students spending a vacation somewhere close to the Arctic Circle. The story begins with the boys walking down a snowy road, chatting about whether they should cross the border for fun or not:

Savoy: Imagine this, every day thousands of people cross the border to get out. We're crossing it to get in.

Mitch: See ya'.

K.C.: You want to tell everyone you were the first asshole to ever do it?

Savoy: No, no, no, I want to take pictures with your camera.

The students continue their travel along the narrow road, in the middle of snowy wilderness and soon they arrive at a border crossing point where a Soviet border guard with a rifle in hand is smoking. The discussion continues quietly:

Mitch: This is the Iron Curtain.

Savoy: This is really something. You know K.C., I bet your pictures make the cover of Time.

K.C.: Make the cover of Moscow Tribune if you guys don't shut up.

Mitch: Hey just think about it. Like a couple hundred feet away one of our fellowmen there's never even tasted a Coca Cola. 
K.C.: They drink Pepsi here. Listen, don't you think we should get back?

Savoy: You go back if you want K.C. I'm gonna check it out.

K.C.: C'mon, so what, you can't be serious?

Savoy: Why not? I mean who could object to a friendly little visit?

And they cross the Iron Curtain and they get caught, captured, thrown in jail and tortured by the Soviet officers in a brutal manner. The film draws an image in which the Russian law enforcement system is represented as absurdly arbitrary, corrupt and disorderedly. Among Russian researchers these two Harlin films, Born American and 5 Days of War, have been considered stereotyping, accusatory and insulting (see Fedorov 2012). After Born American was released in January 1986, the ambassador of the Soviet Union, Vladimir Sobolev, demanded the film be censored. Sobolev brought up the issue on the level of the Foreign Ministry and stated that showing the film would not be in line with "the statements of our countries' leaders, according to which the friendship, trust and good neighborliness between our countries must be guarded and developed" (Suomi 2008, 71). Accordingly, the Finnish National Board of Film Classification banned the film on January 14, arguing that the film "may worsen the state's relations with foreign powers" (Sedergren 1999, 484). This stance was based on a law established in 1965, according to which films that may endanger security and defense or worsen relations with foreign powers must be censored (Suomi 2008, 71-72). After a trial in the Supreme Administrative Court of Finland in December 1986, the ban was removed and a version that excluded the most sensitive scenes concerning foreign policies was permitted (Sedergren 1999, 484-485).

Born American is one of the best examples of what so-called Finlandization of media has meant in practice. The term 'Finlandization' was invented in the late 1960s by the German political media to refer to Finland as an example of a small nation that is forced to adjust its foreign policies according to the control of a more powerful neighbor. The roots of the period of Finlandization are commonly traced back to the Treaty of Friendship, Cooperation and Mutual Assistance concluded by the Finns with the Soviet Union, in 1948 (Moisio, 2008, 83). Generally speaking, Finlandization has often been used as a term to describe a political strategy for 'coping with a greedy neighbour' (Wiberg 1989). The term has shifted away from its origin and is commonly used outside its original geopolitical contexts, for example the discussion about the Finlandization of Taiwan, in the face of Chinese influence (Gilley 2010).

As a process of bordering, Finlandization has meant a textually and discursively (re)produced interterritoriality in which, through different forms of media, people were socialized to the supposition that the Soviet Union represented a threat to them (see Newman and Paasi 1998, 196). Internal political decisions were substantially influenced by the Soviet Union, at the same time altering the (national) selfunderstanding of the Finnish people (Paasi 1996). In the case of the media, the politics of Finlandization meant self-censorship. The period of Finlandization is generally considered to have terminated at the end of the Cold War, and especially when Finland joined the EU in 1995 - although it is still questioned whether the days of Finlandization are actually over (Ridanpää 2012). A recent debate over Finland's 'postCold War' Finlandization popped up when the government decided to approve the 
purchase of a Russian-built nuclear reactor - at height of the Ukraine crisis, a time when the strategic line of the EU has been to decrease all trade with Russia to a minimum (Milne 2014). During the Cold War, censorship in popular media was commonly cautious self-censorship, but as in case of Born American, enforcement by Soviet officials was also usual. For example, the computer game Raid Over Moscow, published in 1984, was considered by Soviet officials as anti-Soviet war propaganda and led to a diplomatic protest which was processed all the way to the Finnish Ministry of Foreign Affairs (Pasanen 2011). Born American was the last film in Finland that was censored on the grounds of foreign policy (Sedergren 1999, 484).

\section{Discussion}

This paper has dissected how the theme of border crossing, from Finland to the Soviet Union, has turned into a geopolitically charged topic in Finnish films. In global media border crossing has been a constantly topical issue and as long as state borders are maintained as more closed than open, the conflicts and fierce debates over foreign policies across different countries will continue to occur. During autumn 2014 the border between Finland and Russia and the issues related to foreign policies, in this case the Russian airspace violations, became a hot topic in the media: "Third Russian airspace violation in a week; Finland steps up air surveillance", as reported by Yle News on 28 August 2014 (Yle 2014). Although these (peacetime) airspace violations are not analogous to the filmic events studied in this paper, it is still worth underlining that when political circumstances change, the audience is often able to find new political aspects and layers from the films.

In the case of Finland the geopolitical meanings of filmic border crossing are rooted in the political history of Finland as a nation, the process of achieving independence, and the struggle to sustain it and so on. It is axiomatic that the Russian/Soviet viewpoint has not been present in these films. However, in Russian films in which the border is crossed into other direction, it becomes in parallel manner evident how crossing a border is a site of action in which nationalist agendas become strongly manifested, taking different shapes and forms when the political climates of Russian society change (Kudrjavtseva 2010). Ultimately, it is the audience who makes the decision about the political nature of the film, and as is evident from film reviews, different audiences can have maximally opposing interpretations concerning the way a certain film is or is not politically charged (Ridanpää 2014). In addition every film contains several layers, which can be politically charged in different ways, and some of these layers are visible only to some audiences while others are not. The geopolitical perspective and position of a viewer is thus highly important in terms of how films become interpreted and consumed (Dodds 2008b).

The examples discussed in this paper open up several questions concerning how geopolitical circumstances are related to films and the film industry. The films presented here stand as good examples of films in which the geopolitical content and dimensions of national borders are negotiated - through the narratives of love, war, national pride and action. It is important to understand that these films do not simply 
discuss the border theme, but that borders themselves, in a relational manner, are situated and constructed within these films. Films that are associated with such sociopolitical process as war propaganda, nation-building and Finlandization are not just reflections of bordering, but rather cultural practices in which the very process of bordering happens. What these examples illustrate is how film that focus on the problematics of border crossing have a certain operational function within the context of their own makings - that is, films work as geopolitical agents, playing their own unique role in the process by which geopolitical order becomes negotiated.

\section{References}

Ahonen, K., R. Merivirta, H. Mulari, and R. Mähkä. 2013. Introduction: Encounters with Borders. In Fronties of Screen History: Imagining European Borders in Cinema, 1945-2010, ed. by R. Merivirta, K. Ahonen, H. Mulari, and R. Mähkä, 1-16. Chicago: Intellect.

Anaz, N., and D. Purcell 2010. Geopolitics of Film: Valley of the Wolves-Iraq and Its Reception in Turkey and Beyond. The Arab World Geographer 13, no. 1: 34-49.

Arreola, D.D. 2005. Forget the Alamo: The Border as Place in John Sayles' Lone Star. Journal of Cultural Geography 23, no. 1: 23-42.

Ball, S. 2014. On the "Doing" of Visual Research on Borders and Migration: Collaboration between Professional Photographers, Social Scientists and Subjects. Journal of Borderlands Studies 29, no.2: 147-164.

Beckham, J.M. 2005. Border Policy/Border Cinema: Placing Touch of Evil, The Border, and Traffic in the American Imagination. Journal of Popular Film and Television 33, no. $3,130-141$.

Billig, M. 1995. Banal Nationalism. London: Sage.

Black, J. 2004. The Geopolitics of James Bond. Geopolitics 19, no. 2, 290-303.

Carter, S., and D.P. McCormack. 2006. Film, Geopolitics and the Affective Logics of Intervention. Political Geography 25, no.2: 228-245.

Celli, C. 2011. National Identity in Global Cinema: How Movies Explain the World. New York: Palgrave Macmillan.

Coulter, K. 2011. Film Geopolitics in Practice: Marketing The Miracle of Bern. Geopolitics 16, no.4, 949-968.

Coulter, K. 2013. Territorial Appeals in Post-Wall German Filmmaking: The Case of Good Bye, Lenin! Antipode 45, no. 3: 760-778. 
Dalby, S. 2008. Warrior geopolitics: Gladiator, Black Hawk Down and The Kingdom of Heaven. Political Geography 27, no. 4, 439-455.

Dell'agnese, E. 2005. The US-Mexico Border in American Movies: A Political Geography Perspective. Geopolitics 10, no. 2, 204-221.

Dittmer, J. 2011. American exceptionalism, visual effects, and the post-9/11cinematic superhero boom. Environment and Planning D: Society and Space 29: 114-130.

Dittmer, J., and N. Gray. 2010. Popular Geopolitics 2.0: Towards New Methodologies of the Everyday. Geography Compass 4, no. 11: 1664-1677.

Dodds, K. 2003. Licensed to Stereotype: Geopolitics, James Bond and the Spectre of Balkanism. Geopolitics 8, no. 2, 125-156.

Dodds, K. 2005. Screening Geopolitics: James Bond and the Early Cold War films (1962-1967). Geopolitics 10, no.2, 266-289.

Dodds, K. 2008a. 'Have You Seen Any Good Films Lately?' Geopolitics, International Relations and Film. Geography Compass 2, no. 2: 476-494.

Dodds, K. 2008b. Hollywood and the popular geopolitics of the war on terror. Third World Quarterly 29: 1621-37.

Dodds, K. 2013. 'I'm Still Not Crossing That': Borders, Dispossession, and Sovereignty in Frozen River (2008). Geopolitics 18: no. 3: 560-583.

Escher, A. 2006. The Geography of Cinema - A Cinematic World. Erdkunde 60, no. 4, 307-314.

Fairclough, N. 1992a. Intertextuality in Critical Discourse Analysis. Linguistics and Education 4: 269-293.

Fairclough, N. 1992b. Discourse and Text: Linguistic and Intertextual Analysis within Discourse Analysis. Discourse \& Society 3, no. 2: 193-217.

Fairclough, N. 1993. Critical discourse analysis and the marketization of public discourse: The universities. Discourse \& Society 4, no. 2, 133-168.

Fedorov, A.V. 2012. The Analysis of Stereotypes of Politically Engaged Media Texts in Media Studies in Student Audience (by the Example of Renny Harlin's films "Born American" (1986) and "Five Days of War" (2011). European Researcher 35, no. 11-3: 2037-2041.

Fojas, C. 2007. Bordersploitation: Hollywood Border Crossers and Buddy Cops. symploke 15, no. 1-2, 80-99. 
Gallagher, J. 2013. Between Hamburg and Istanbul: Mobility, Borders and Identity in the Films of Fatih Akin. In Fronties of Screen History: Imagining European Borders in Cinema, 1945-2010, ed. by R. Merivirta, K. Ahonen, H. Mulari, and R. Mähkä, 175194. Chicago: Intellect.

Gilley, B. 2010. Not So Dire Straits: How Finlandization of Taiwan Benefits U.S. Security. Foreign Affairs 89, no. 1: 44-60.

Haddad, E. 2007. Danger Happens at the Border. In Borderscapes: Hidden Geographies and Politics at Territory's Edge, ed. by P.K. Rajaram and C. GrundyWarr, 119-136. Minnesota: University of Minnesota Press.

Heinonen, V. 1998. Talonpoikainen etiikka ja kulutuksen henki:

Kotitalousneuvonnasta kuluttajapolitiikkaan 1900-luvun Suomessa. Helsinki: Hakapaino.

Häkli, J. 1999. Cultures of Demarcation: Territory and National Identity in Finland. In Nested Identities: Nationalism, Territory, and Scale, ed. by G.H. Herb and D.H. Kaplan, 123-150. Lanham: Rowman and Littlefield.

Jokinen, K., and M. Linko. 1987. Uusi Tuntematon. Rauni Mollbergin ohjaaman Tuntematon sotilas -elokuvan ensi-illan aikainen vastaanotto. Jyväskylä: Jyväskylän yliopisto.

Karemaa, O. 2004. Moraalisesta närkästyksestä kansalliseksi ohjelmaksi. In Venäjän Kahdet Kasvot: Venäjä-kuva Suomalaisen Identiteetin Rakennuskivenä, ed. by T. Vihavainen, 226-254. Helsinki: Edita Prima Oy.

Kirchick, J. 2011. Daze of War: The Russia-Georgia Conflict on Film. World Affairs 174 , no. $4,92-96$.

Koppes, C.R., and G.D. Black. 1987. Hollywood goes to war: How politics, profits, and propaganda shaped World War II movies. Berkeley: University of California Press.

Kosonen, K. 2008. Making maps and mental images: Finnish press cartography in nation-building, 1899-1942. National Identities 10, no. 1:21-47.

Kudrjavtseva, T. 2010. Cultural Boundaries and Intercommunication in Two Films from the North-West of Russia. Journal of Borderlands Studies 25, no. 1: 59-65.

Lam, K. 2012. Homes across the Border: Russian Summer Houses in the Karelian Isthmus and the Finnish State, 1917-1927. Journal of Borderlands Studies 27, no. 3: 331-343.

Lukinbeal, C. 2005. Cinematic landscape. Journal of Cultural Geography 23, no. 1, 322 . 
Maciel, D.R. 1990. El Norte: The U.S.-Mexican Border in Contemporary Cinema. San Diego: Institute for Regional Studies of the Californias, San Diego University.

Madsen, K.D. 2014. Blue Indians: Teaching the Political Geography of Imperialism With Fictional Film. Journal of Geography 113, no. 2: 47-57.

Mains, S.P. 2004. Imagining the border and Southern spaces: Cinematic explorations of race and gender. GeoJournal 59: 253-264

Miller, J. 2013. 'What's Wrong with a Cowboy in Hamburg?' New German Cinema and the German-American Cultural Frontier. In Fronties of Screen History: Imagining European Borders in Cinema, 1945-2010, ed. by R. Merivirta, K. Ahonen, H. Mulari, and R. Mähkä, 41-64. Chicago: Intellect.

Milne, R. 2014. 'Finlandisation' makes a polarising comeback in Finland. The Financial Times 24 September 2014. http://www.ft.com/cms/s/0/cbb17c76-435c-11e4be3f-00144feabdc0.html\#axzz3KLNmpOTw

Moisio, S. 2008. Finlandisation versus westernisation: Political recognition and Finland's European Union membership debate. National Identities 10, no. 1: 77-93.

Murdock, J. 2006. Post-Structuralist Geography. London: Sage.

Mällinen, J. (2012). Yle esittää Tuntemattoman sotilaan itsenäisyyspäivänä soraäänistä huolimatta. Yle Uutiset 4 December 2012. http://yle.fi/uutiset/yle esittaa tuntemattoman sotilaan itsenaisyyspaivana soraaanista huolimatta/6403102

Newman, D., and A. Paasi. 1998. Fences and neighbours in the postmodern world: boundary narratives in political geography. Progress in Human Geography 22, no.2: 186-207.

Ó Tuathail, G. 1996. Critical geopolitics. Minneapolis: University of Minnesota Press.

Ó Tuathai, G., and S. Dalby. 1998. Introduction: Rethinking geopolitics. In Rethinking Geopolitics, ed. by G.Ó Tuathail and S. Dalby, 1-15. London: Routledge.

Paasi, A. 1996. Territories, Boundaries and Consciousness: The Changing Geographies of the Finnish-Russian Border. Chichester: John Wiley \& Sons.

Paasi, A. 1999. Boundaries as Social Practice and Discourse: The Finnish-Russian Border. Regional Studies 33, no. 7: 669-680.

Paasi, A. 2011. A Border Theory: An Unattainable Dream or a Realistic Aim for Border Scholars? In The Ashgate Research Companion to Border Studies, ed. by D. Wastl-Walter, 11-31. Farnham: Ashgate. 
Paasi, A. and E.-K. Prokkola. 2008. Territorial Dynamics, Cross-border Work and Everyday Life in the Finnish-Swedish Border Area. Space and Polity 12, no. 1: 13-29.

Pasanen, T. 2011. "Hyökkäys Moskovaan!" - Tapaus Raid over Moscow Suomen ja Neuvostoliiton välisessä ulkopolitiikassa 1980-luvulla. In Pelitutkimuksen vuosikirja 2011, ed. by J. Suominen, R. Koskimaa, F. Mäyrä, O. Sotamaa and R. Turtiainen, 111. Tampere: University of Tampere.

Power, M., and A. Crampton. 2005. Reel Geopolitics: Cinemato-graphing Political Space. Geopolitics 10, no. 2: 193-203.

Prokkola, E.-K., and J. Ridanpää. 2014. Border guarding and the politics of the body: an examination of the Finnish Border Guard service. Gender, Place \& Culture: A Journal of Feminist Geography, DOI: 10.1080/0966369X.2014.970136.

Rajaram, P.K., and C. Grundy-Warr, eds. 2007, Borderscapes: Hidden Geographies and Politics at Territory's Edge. Minnesota: University of Minnesota Press.

Ridanpää, J. 2012. The Media and the Irony of Politically Serious Situations: Consequences of the Muhammed Cartoons in Finland. Media, Culture \& Society. 34, no. 2: 131-145.

Ridanpää, J. 2014. 'Humour is Serious' as a Geopolitical Speech Act: IMDb Film Reviews of Sacha Baron Cohen's The Dictator. Geopolitics 19, no. 1, 140-160.

Scharf, I. 2005. Staging the Border: National Identity and the Critical Geopolitics of West German Film. Geopolitics 10, no. 2: 378-397.

Schimanski, J. 2015. Border Aesthetics and Cultural Distancing in the NorwegianRussian Borderscape, Geopolitics 20, no. 1: 35-55.

Sedergren, J. 1999. Filmi poikki... Poliittinen elokuvasensuuri Suomessa 1939-1947. Helsinki: Hakapaino.

Sedergren, J. 2006. Taistelu elokuvasensuurista: Valtiollinen elokuvatarkastus Suomessa 1946-2006. Helsinki: Suomalaisen Kirjallisuuden Seura.

Suodenjoki, S. 2012. Kansalaisyhteiskunnan ja Suomen ideat, liikkeet ja julkisuudet ennen vuotta 1917. In Suomalaisen politiikan murroksia ja muutoksia, ed. by K. Paakkunainen, 53-74. Helsinki: Unigrafia.

Suomi, J. 2008. Kohti sinipunaa: Mauno Koiviston aika 1986-1987. Keuruu: Otava.

Szary, A.-L.A. 2012. Walls and Border Art: The Politics of Art Display. Journal of Borderlands Studies 27, no. 2, 231-228. 
Uusitalo, K. 1977. Ruutia, riitoja, rakkautta... Suomalaisen elokuvan sotavuodet 1940-1948. Vammala: Vammalan kirjapaino oy.

Varpio, Y. 2006. Väinö Linnan elämä. Porvoo: WSOY.

Vihavainen, T. 2004. Ryssistä neukuiksi ja neukuista venäläisiksi - vallankumous naapurikuvassa. In Venäjän Kahdet Kasvot: Venäjä-kuva Suomalaisen Identiteetin Rakennuskivenä, ed. by T. Vihavainen, 359-377. Helsinki: Edita Prima Oy.

Wiberg, H. 1989. Coping with a Greedy Neighbour. Journal of Peace Research 26, no. 3: 319-325.

Yle. 2014. Third Russian airspace violation in a week; Finland steps up air surveillance. Yle Uutiset 28 August 2014.

http://yle.fi/uutiset/third_russian_airspace_violation_in_a_week_finland_steps_up_air_ surveillance/7438235 